\title{
Liver Enzyme Alterations in HCV-Monoinfected and HCV/HIV-Coinfected Patients
}

\author{
Klaus Langohr ${ }^{1,2}$, Arantza Sanvisens ${ }^{1}$, Daniel Fuster ${ }^{1}$, Jordi Tor ${ }^{1}$, Isabel Serra ${ }^{1}$, Celestino Rey-Joly ${ }^{1}$, \\ Inmaculada Rivas ${ }^{3}$ and Roberto Muga ${ }^{*}, 1$ \\ ${ }^{I}$ Department of Internal Medicine, Hospital Universitari Germans Trias i Pujol, Badalona, Spain \\ ${ }^{2}$ Human Pharmacology and Clinical Neurosciences Research Unit. Institut Municipal d'Investigació Mèdica / IMIM, \\ Barcelona, Spain \\ ${ }^{3}$ Municipal Centre for Drug Abuse Treatment (Centro Delta), Badalona, Spain
}

\begin{abstract}
Hepatitis C virus (HCV) is the most common blood-borne infection in developed countries and co-infection with the Human Immunodeficiency Virus (HIV) is frequent in individuals with history of injecting drug use (IDU).

We aimed to analyze liver transaminases in HCV monoinfected and HCV/HIV co-infected patients to assess the effect of HIV infection on liver enzyme elevations.

We studied 429 current IDUs admitted to substance abuse treatment ( $82.5 \%$ males). Serum samples for liver tests, HIV infection and viral hepatitis serologies were obtained at admission. Results: Median age was 30 years (IQR:27-34), median duration of IDU was 10 years (IQR:5-14), 52\% of patients were HCV/HIV co-infected, 40.8\% were HCV monoinfected, and $7.2 \%$ were $\mathrm{HCV}$ and HIV- seronegatives. Elevated AST was associated with male gender and lower CD8 ${ }^{+}$cell count in the HCV monoinfected patients, and with age and lower cholesterol in the HCV/HIV coinfected subjects. ALT elevation was associated with younger age, higher body mass index and male gender in the monoinfected patients, and with higher $\mathrm{CD}^{+}$cell counts and lower cholesterol in the co-infected group. Male sex was strongly associated with elevated ALT and AST transaminase in the monoinfected but not in dual-infected subjects.

These data suggest that the effect of gender on liver enzymes may be lost in patients with HIV infection. The overall differences observed between groups regarding liver enzyme elevations are of clinical relevance in the management of IDUs with chronic hepatitis $\mathrm{C}$.
\end{abstract}

Keywords: Aspartate aminotransferase (AST), alanine aminotransferase (ALT), correlates of hepatic transaminase elevations, HIV/hepatitis C co-infection, injection drug users.

\section{INTRODUCTION}

Serum transaminase measurements are widely used in the management of chronic hepatitis C. Despite intravenous drug use has been associated with lower levels of alanine aminotransferase (ALT) [1], elevations of liver enzymes are frequent in patients with a history of substance abuse. Potential cofactors contributing to liver disease in IDUs are viral hepatitis, alcohol consumption and drug induced hepatotoxicity. Previous studies have shown that the HCV-monoinfected individuals have higher levels of aspartate aminotransferase (AST), ALT, and Gamma-Glutamyl-Transferase (GGT) than the uninfected $[1,2]$ and that ALT levels decrease with age $[1,3]$ and have been associated with body mass index (BMI) [4].

$\mathrm{HCV}$ is the most common blood-borne infection in developed countries and injection drug use accounts for $60 \%$ of new HCV infections [5]. In IDU populations at risk of Human Immunodeficiency Virus (HIV) infection, the prevalence of

*Address correspondence to this author at the Department of Internal Medicine, Hospital Universitari Germans Trias i Pujol. Room 806, Carretera Canyet s/n, 08916 Badalona, Barcelona, Spain; Tel: (+34) 93-497 89 14; Fax: (+34) 93-497 88 43; E-mail: rmuga.germanstrias@gencat.cat
$\mathrm{HCV}$ is high due to shared transmission mechanisms; in this context of parenteral transmission, hepatitis $\mathrm{C}$ virus infection is usually acquired at the beginning of injection drug use [6].

The role of liver enzymes in the assessment of chronic hepatitis $\mathrm{C}$ remains important due to the fact that the majority of clinical indexes estimating the degree of liver fibrosis are based in liver transaminases [7-12]; these non-invasive methods to estimate liver fibrosis provide information into progression of liver disease and they are an important alternative to liver biopsy in populations such as IDUs not being elegible for liver biopsy

Regarding the role of cellular immune response to $\mathrm{HCV}$ infection it has been thought to be crucial in the inhibition of hepatitis C viral replication. Several studies have reported that $\mathrm{CD} 8^{+}$lymphocytes play a key role as effectors of liver damage during chronic HCV infection [13-15]. On the other hand, total serum cholesterol, triglycerides and glucose have been linked to liver transaminase levels in healthy populations [16]. Alterations of lipid metabolism, particularly in apolipoproteins $\mathrm{B}$ and $\mathrm{C}$ have been described in hepatitis $\mathrm{C}$ with genotype $1 \mathrm{~b}$ or $3 \mathrm{a}[17,18]$ and hypocholesterolemia has 
been associated with HCV infection and HCV/HIV coinfection $[19,20]$.

The objective of this study is to analyze correlates of liver enzyme alterations in HCV monoinfected and HCV/HIV co-infected patients with history of IDU to better understand the role of HIV infection on liver transaminase alterations.

\section{PATIENTS AND METHODS}

\section{Study Population}

Between 1994 and 2004, 498 IDUs were admitted to substance abuse treatment at University Hospital Germans Trias i Pujol in Badalona (Spain). Briefly, patients seeking substance abuse treatment in primary care centers of metropolitan Barcelona (Badalona and Santa Coloma de Gramenet) were referred to a four-bed detoxification unit in a tertiary hospital. Patients were primarily referred to hospital due to severity of addiction. Additional details on the criteria for admission and characteristics of patients have been published elsewhere [21].

During admission, patients provide data on sociodemographics (age and gender) and drug use characteristics (main drug, duration of injection, alcohol consumption), current medications and history of HIV and HCV treatments. Patients also provide blood samples for the analysis of liver enzymes, total cholesterol, $\mathrm{CD} 4^{+}$and $\mathrm{CD} 8^{+}$cells, hepatitis $\mathrm{B}$ virus surface antigen (HBsAg), HIV, and $\mathrm{HCV}$ infections.

Liver enzyme testing was performed the same day of blood collection using a multi-channel chemistry analyzer (DAX-48, Bayer Diagnostics). All analyses were performed with reagents and instrumental conditions exactly as specified by the instrument manufacturer. A normal liver enzyme value was defined according to the range established by the department of Clinical Chemistry. The range of liver enzyme values was characterized as a function of the upper limit of normal. Abnormal levels of AST and ALT were defined as $>$ $35 \mathrm{U} / \mathrm{l}$ and $>45 \mathrm{U} / \mathrm{l}$, respectively. An abnormal level of GGT was defined as $>85 \mathrm{U} / 1$ in males and $>50 \mathrm{U} / \mathrm{l}$ in females.

HIV infection was determined by enzyme-linked immunosorbent assay. Repeatedly reactive samples were confirmed by Western blot.

$\mathrm{HCV}$ infection was assessed by second- or later generation enzyme immunoassay (Ortho Diagnostics, Raritan, NJ). HCV RNA testing was performed in frozen sera using the qualitative COBAS AMPLICOR assay (Roche Diagnostic Systems, Branchburg, NJ). This test was applied retrospectively to sera collected during the study period.

For the purposes of this study, patients were eligible if they had both an HCV and an HIV test during admission. Sixty nine cases (13.9\%) were excluded from the study population: 4 patients because they had liver enzyme elevations $>10$-fold above the upper limit of normal (ULN) and 27 individuals due to missing information on either $\mathrm{HCV}$ or HIV infection. Among the remaining 467 patients, 38 (8.1\%) were excluded from the study because of an HCV RNAnegative test result.

\section{Statistical Analysis}

Three groups were defined according to their $\mathrm{HCV}$ and HIV serostatus: HCV monoinfected, HCV/HIV coinfected and those without either infection. The univariate comparison of these three groups was carried out by means of either Fisher's exact test for categorical variables or the nonparametric Kruskal-Wallis test for quantitative variables. All other analyses were carried out separately for both mono- and coinfected patients. Univariate odds ratios of the risk of AST and ALT elevations were calculated for men and women. Correlations of $\mathrm{CD}^{+}$and $\mathrm{CD} 8^{+}$cells with liver enzymes were determined by means of Pearson's correlation coefficient. To identify predictors of elevated values of AST, ALT, and GGT, multivariate logistic regression models were adjusted for age, gender, alcohol consumption, duration of injection drug use, BMI, total cholesterol, antiretroviral treatment (in case of coinfected individuals), $\mathrm{CD} 4^{+}$cell count, and $\mathrm{CD} 8^{+}$cell count as possible predictors. Stepwise forward selection was used to identify predictors among these variables using $\alpha=0.05$ and $\alpha=0.1$ as inclusion and exclusion criteria, respectively. The test of Hosmer and Lemeshow [22] was used to check the goodnessof-fit of the models.

Because of the right-skewed distributions of $\mathrm{CD}^{+}$and $\mathrm{CD} 8^{+}$cell counts and the liver enzymes, the logarithms (base 10) of the respective values were used for the statistical analyses. Due to the fact that the range of the logarithm of the number of $\mathrm{CD}^{+}$and $\mathrm{CD} 8^{+}$cells was close to one, the results from the multivariate logistic regression are expressed as odds ratios corresponding to an increase of a quarter of a logarithm of either $\mathrm{CD} 4^{+}$or $\mathrm{CD} 8^{+}$cells. Such an increase is equivalent to an increase from 250 to 450 cells, from 400 to 710 cells, or from 600 to 1050 cells.

The test results were considered statistically significant whenever $P<0.05$. Statistical analyses were performed with SPSS 12.0 (SPSS, Chicago, IL, USA).

\section{RESULTS}

A total of 429 IDUs were included in the study, 175 (40.8\%) of whom were $\mathrm{HCV}^{+} / \mathrm{HIV}^{-}$(monoinfected patients). In addition, 223 patients $(52 \%)$ were $\mathrm{HCV}^{+} / \mathrm{HIV}^{+}$coinfected and, 31 (7.2\%) were HCV and HIV seronegative. The characteristics of the three groups are shown in Table $\mathbf{1}$.

We observed significant differences in age, alcohol intake, and duration of IDU among the groups. On average, HCV/HIV coinfected patients were significantly older than the non-infected and presented the longest duration of injecting drugs. The median duration of IDU was 12 years in the co-infected patients compared to 7.5 years among the monoinfected and 1.5 years among the non-infected patients. The highest prevalence of alcohol consumption was observed among non-infected patients were almost $50 \%$ of them reported alcohol consumption at entry.

The median values of total cholesterol and BMI were lower among co-infected patients. However, the differences in BMI were rather small: $21.5 \mathrm{~kg} / \mathrm{m}^{2}$ among coinfected patients vs $21.7 \mathrm{~kg} / \mathrm{m}^{2}$ among non-infected and $22 \mathrm{~kg} / \mathrm{m}^{2}$ among monoinfected subjects. 
Table 1. Baseline Characteristics of 429 IDUs According to HCV and HIV Serostatus

\begin{tabular}{|c|c|c|c|c|}
\hline & $\mathrm{HCV}^{+} / \mathrm{HIV}^{-}$ & $\mathrm{HCV}^{+} / \mathrm{HIV}^{+}$ & $\mathrm{HCV}^{\circ} / \mathrm{HIV}^{-}$ & $P$-Value \\
\hline $\mathbf{N}(\%)$ & $175(40.8)$ & $223(52.0)$ & $31(7.2)$ & \\
\hline \multicolumn{5}{|l|}{ Sociodemographic and drug use } \\
\hline Male gender & $146(83.4)$ & $179(80.3)$ & $29(93.5)$ & 0.167 \\
\hline Age in years & $30(26-34)$ & $31(28-35)$ & $27(23-32)$ & 0.002 \\
\hline Alcohol consumption $\geq \mathbf{4 0} \mathrm{g} / \mathrm{day}$ & $38(21.7)$ & $67(30.0)$ & $15(48.4)$ & 0.005 \\
\hline Duration of IDU in years & $7.3(3.9-12.0)$ & $12.0(8.0-16.0)$ & $1.5(0.5-6.0)$ & $<0.001$ \\
\hline \multicolumn{5}{|l|}{ Liver enzymes and other variables } \\
\hline Aspartate aminotransferase (U/l) & $32.5(20-56.3)$ & $38(27-67)$ & $17(12.8-28.8)$ & $<0.001$ \\
\hline$\% \mathrm{AST}>35 \mathrm{U} / \mathrm{l}$ & 46 & 54.4 & 13.3 & \\
\hline Alanine aminotransferase (U/l) & $54(22.8-99)$ & $44.5(27.8-73)$ & $20.5(12.8-37.3)$ & $<0.001$ \\
\hline$\%$ ALT $>45 \mathrm{U} / \mathrm{l}$ & 57.5 & 48.6 & 13.3 & \\
\hline Gamma glutamyltransferase (U/I) & $32(18-52.5)$ & $51(25-101)$ & $20(13.5-33)$ & $<0.001$ \\
\hline$\%$ GGT $>85$ (males) $/>50$ (females) & 16.8 & 34.3 & 10.3 & \\
\hline Alkaline phosphatase (U/l) & $68.5(54-81.3)$ & $70(58.5-88.3)$ & $65.5(57-88.5)$ & 0.193 \\
\hline Bilirrubin (mg/100ml) & $0.4(0.3-0.5)$ & $0.4(0.3-0.6)$ & $0.4(0.3-0.5)$ & 0.109 \\
\hline Total cholesterol (mg/100ml) & $159(143-178)$ & $147(128-166)$ & $174.5(159-201)$ & $<0.001$ \\
\hline Body mass index $\left(\mathrm{kg} / \mathrm{m}^{2}\right)$ & $22(20.7-24.2)$ & $21.5(19.3-23.4)$ & $21.7(20.4-24.1)$ & 0.037 \\
\hline HBsAg $^{+}$ & $7(4.1)$ & $18(9.0)$ & $1(3.4)$ & 0.122 \\
\hline Current use of antiretroviral treatment & --- & $58(26.0)$ & --- & \\
\hline \multicolumn{5}{|l|}{ Immunological markers } \\
\hline $\mathrm{CD4}^{+}(\mathrm{cel} / \mu \mathrm{l})$ & $1220(911.3-1429.5)$ & $390(195.5-650)$ & $1267(1043-1440)$ & $<0.001$ \\
\hline $\mathrm{CD8}^{+}(\mathrm{cel} / \mu \mathrm{l})$ & $864(701-1134.5)$ & $900(665.3-1302.8)$ & $891(725-1120)$ & 0.554 \\
\hline
\end{tabular}

NOTE. Results are expressed as median (interquartile range) for continuous variables and absolute frequency (\% among non-missing observations) for categorical variables. $P$-values by Kruskal-Wallis test (continuous variables) and $\chi^{2}$-test (categorical variables).

Regarding liver enzymes, AST and ALT levels were significantly different between the three groups with highest median values among the co-infected (AST and GGT) and monoinfected patients (ALT), respectively. The median levels of total bilirubin and alkaline phosphatase were similar among groups $(P>0.1)$. Finally, whereas the number of $\mathrm{CD} 8^{+}$ cells was about the same in all groups, the number of $\mathrm{CD} 4^{+}$ cells in the HCV/HIV coinfected patients was, as expected, less than a third the level in either of the two other groups.

Among the $\mathrm{HIV}^{+}$IDUs, only $58(26.0 \%)$ were taking antiretroviral treatment at admission. Among those HIV+ IDUs not taking ARV medication, 57.7\% of them had more than $350 \mathrm{CD} 4^{+}$cells.

\section{Prevalence of Elevated AST, ALT, and GGT}

The proportions of patients with elevated AST, ALT, and GGT levels are shown in Table 1. In all cases, the lowest proportions of altered levels were observed among the non-infected IDUs: $13.3 \%$ (AST and ALT) and 10.3\% (GGT). In order to examine the effect of HIV on the liver enzyme alterations of individuals with chronic hepatitis $\mathrm{C}$, the non-infected group was excluded from further comparisons.
Co-infected patients had higher proportions of elevated values of AST (54.4\% vs 46\%) and GGT (34.3\% vs 16.8\%), whereas the proportion of elevated ALT was higher among the monoinfected patients (57.5\% vs 48.6\%). Fisher's exact test showed that differences were significant for ALT $(P=0.05)$ and GGT $(P<0.001)$ and of borderline significance for AST $(P=0.06)$.

\section{Effect of Gender}

Fig. (1) shows that the proportions of elevated AST and ALT levels differed strongly between men and women in the monoinfected but not in the co-infected patients. The estimated univariate odds ratios for elevated AST and ALT levels comparing monoinfected men and monoinfected women were 5.14 (95\% CI:1.86-14.22) and 5.62 (95\% CI: 2.25 14.04), respectively. Contrary to that finding, among coinfected patients, the corresponding odds ratios did not differ significantly ( $P=0.18$ and $P=0.39$, respectively).

\section{Effect of Antiretroviral Treatment}

Among the 58 patients taking antiretroviral treatment, the proportion of elevated values was lower in the case of AST (48.1\% vs 56.5\%) and higher in the case of ALT (50\% vs 

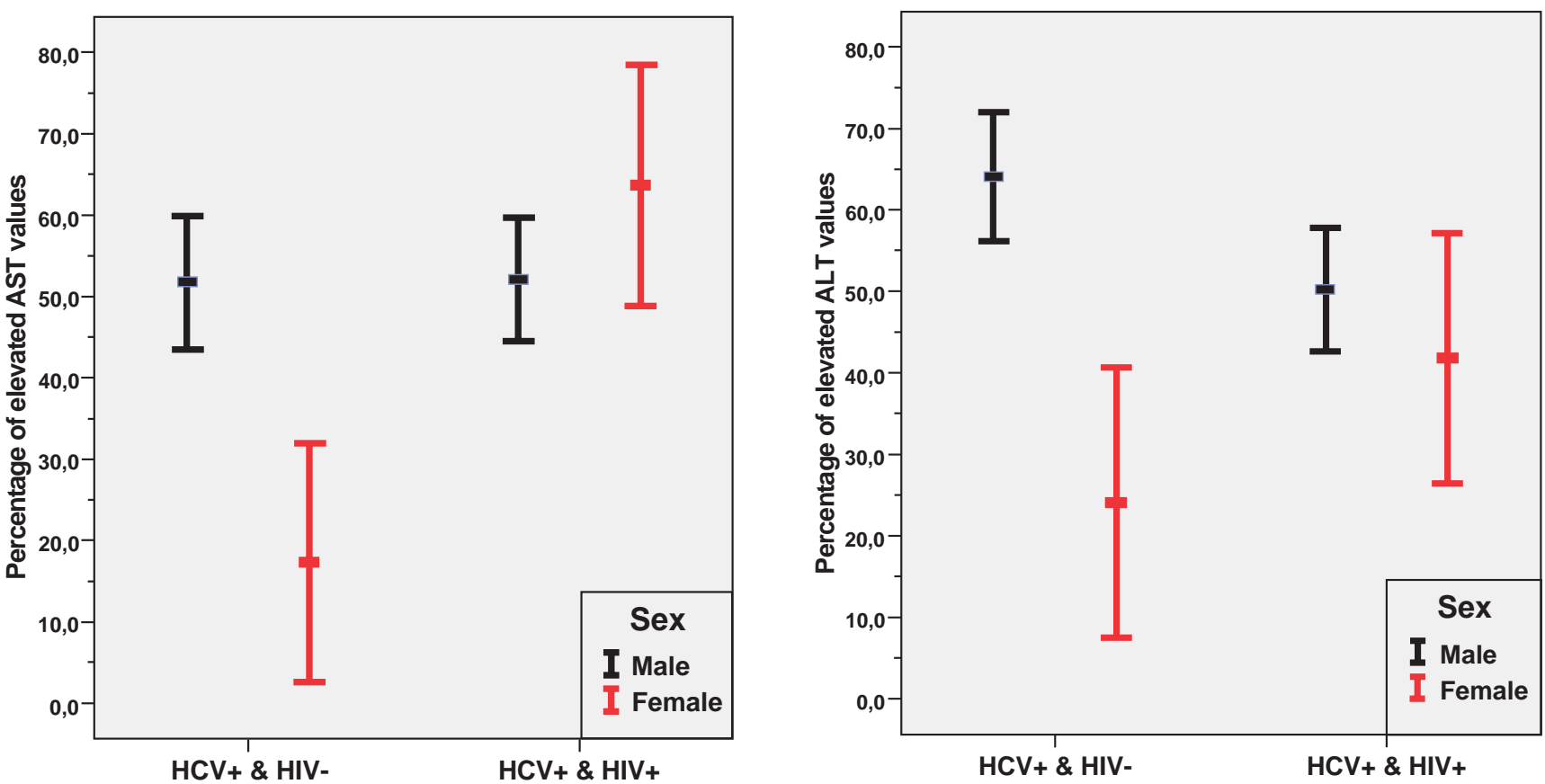

Fig. (1). 95\%-Confidence intervals for proportions of elevated AST and ALT levels according to gender and serologic status of HCV and HIV infections. Confidence intervals are computed using the normal distribution.

$48.1 \%$ ) and GGT (37.7\% vs 33.1\%); however, none of these differences were significant $(P$-values: $0.34,0.87$, and 0.61 , respectively).

\section{Correlation of $\mathrm{CD4}^{+}$and $\mathrm{CD8}^{+}$Cells with Liver Enzymes}

The four panels in Fig. (2) illustrate the correlation of absolute $\mathrm{CD}^{+}$and $\mathrm{CD}^{+}$cell counts with AST and ALT levels, including linear regression lines for both the monoinfected and co-infected subjects.

With respect to $\mathrm{CD}^{+}$, a statistically significant association was found with ALT levels in the co-infected patients, indicating that higher values of $\mathrm{CD}^{+}$cells are associated with higher values of $\mathrm{ALT}(P=0.01)$. For the $\mathrm{CD} 8^{+}$cells, significant associations were observed between AST levels in the monoinfected and ALT levels in both mono- and co-infected patients. Co-infected patients showed, on average, higher levels of ALT with increasing $\mathrm{CD}^{+}$cells, whereas the correlation was negative in monoinfected individuals. In other words, the higher the number of $\mathrm{CD}^{+}$cells, the lower the levels of AST and ALT, respectively. However, none of the correlation coefficients -even though statistically significant- exceeds 0.25 . Correlation coefficients of GGT levels with $\mathrm{CD}^{+}$and $\mathrm{CD}^{+}$ cells were not significantly different from $0(P>0.05)$.

\section{Factors Associated with Elevated AST, ALT, and GGT Levels}

Table 2 shows the results of the multivariate logistic regression models in terms of odds ratios for each of the three liver enzymes analyzed.

AST. Men were at higher risk for elevated AST than women (Odds ratio (OR): 6.31, 95\% confidence interval (CI): 1.74-22.85) in the HCV monoinfected patients. The risk decreased with an increase in $\mathrm{CD}^{+}$cells. The OR corre- sponding to an increase of a quarter of a logarithm of $\mathrm{CD}^{+}$ cells was 0.43 (95\% CI: 0.24-0.76). In contrast, elevated AST in coinfected patients was associated with age and total cholesterol. The odds of elevated AST increased by $42 \%$ with an age increase of five years (OR: $1.42,95 \%$ CI: $1.06-$ 1.89 ), whereas a decrease of total cholesterol by $20 \mathrm{mg}$ implied a reduction in risk of $24 \%$ (OR: $0.76,95 \%$ CI: $0.61-$ 0.93).

Table 2. Adjusted Odds Ratios (OR) for AST, ALT and GGT Elevations in Multivariate Logistic Regression Models

\begin{tabular}{|c|c|c|c|c|}
\hline & \multicolumn{2}{|c|}{$\mathrm{HCV}^{+} / \mathrm{HIV}^{-}$} & \multicolumn{2}{|c|}{$\mathrm{HCV}^{+} / \mathrm{HIV}^{+}$} \\
\hline & & OR $(95 \% \mathrm{CI})$ & & OR $(95 \%$ CI $)$ \\
\hline \multirow[t]{2}{*}{$\mathbf{A S T}$} & $\begin{array}{l}\text { Male } \\
\text { gender }\end{array}$ & $6.31(1.74-22.85)$ & $\begin{array}{c}\text { Total } \\
\text { cholesterol }^{1}\end{array}$ & $0.76(0.61-0.93)$ \\
\hline & $\mathrm{CD}^{+2}$ & $0.43(0.24-0.76)$ & $\mathrm{Age}^{3}$ & $1.42(1.06-1.89)$ \\
\hline \multirow{3}{*}{$\mathbf{A L T}$} & $\begin{array}{l}\text { Male } \\
\text { gender }\end{array}$ & $6.06(2.14-17.12)$ & $\begin{array}{c}\text { Total } \\
\text { cholesterol }^{1}\end{array}$ & $0.79(0.65-0.97)$ \\
\hline & $\mathrm{Age}^{3}$ & $0.61(0.43-0.85)$ & $\mathrm{CD}^{+2}$ & $1.23(1.02-1.48)$ \\
\hline & BMI & $1.16(1.02-1.31)$ & & \\
\hline GGT & $\begin{array}{c}\text { Alcohol } \\
\text { consumption }\end{array}$ & 3.78 (1.56-9.19) & $\begin{array}{c}\text { Alcohol } \\
\text { consumption }\end{array}$ & $2.01(1.02-3.97)$ \\
\hline
\end{tabular}

NOTE. All models were adjusted for gender, alcohol consumption, duration of injection drug use, BMI, total cholesterol, $\mathrm{CD}^{+}$and $\mathrm{CD}^{+}$cell counts. Only significant factors associated with liver enzyme elevations are shown $(P<0.05)$.

I OR for an increase of $20 \mathrm{mg} / 100 \mathrm{ml}$ in total cholesterol.

${ }^{2} \mathrm{OR}$ for an increase of $0.25^{*} \log _{10}$ in CD4+ and CD8+ cells

${ }^{3} \mathrm{OR}$ for five years of age increase.

ALT. Among HCV monoinfected patients, elevation of ALT was associated with age, BMI, and male gender. The 

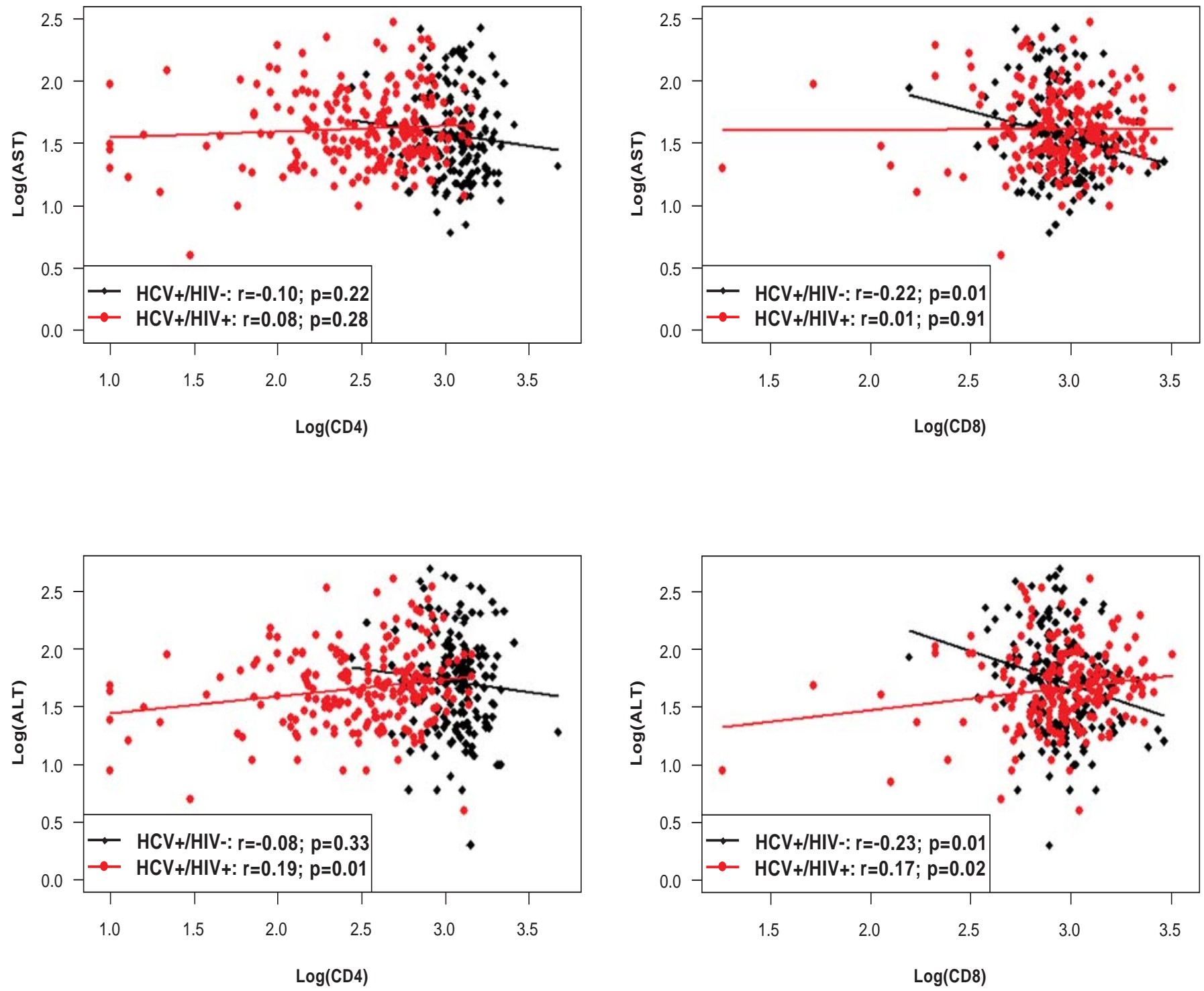

Fig. (2). Correlations of cellular immunity (CD4+ and CD8+ cells) with AST and ALT in HCV+/HIV- monoinfected and HCV+/HIV+ coinfected patients. Results are expressed as $\log (\mathrm{U} / \mathrm{l})$ in case of AST and ALT, and as $\log (\mathrm{cel} / \mu \mathrm{l})$ in case of CD $4^{+}$and $\mathrm{CD} 8^{+}$. P-values correspond to the hypotheses of zero correlation.

estimated OR of men compared to women was $6.06(95 \%$ CI: 2.14-17.12). The risk of elevated ALT declined with (increasing) age (OR for an increase of 5 years: $0.61,95 \% \mathrm{CI}$ : 0.43-0.85) and with increasing BMI (OR: 1.16, 95\% CI: 1.02-1.31). With respect to co-infected patients, the two significant associated factors were total cholesterol and the number of $\mathrm{CD}^{+}$cells. The effect of total cholesterol was similar to the one found for AST (OR 0.79; 95\% CI: $0.65-$ 0.97). On the other hand, an increase of a quarter of the logarithm of $\mathrm{CD}^{+}$cells increased the odds for elevated ALT by $23 \%$ (95\% CI: 1.02-1.48).

GGT. Alcohol consumption increased the odds of elevated GGT values both in the monoinfected and the co- infected individuals. The corresponding OR were $3.78(95 \%$ CI: 1.56-9.19) in monoinfected subjects and 2.01 (95\% CI: 1.02-3.97) in coinfected subjects.

The $P$-value of the Hosmer-Lemeshow test to check model adequacy exceeded 0.05 for all models with more than one predictor variable, indicating satisfactory model fits.

\section{DISCUSSION}

Few data are available regarding the significance of liver enzyme alterations among $\mathrm{HCV}$-infected and among HIV/HCV co-infected IDUs not referred to liver clinics. In this study we evaluated routinary markers of liver disease or 
liver inflammation to analyze the correlates of AST, ALT and GGT elevations. All three parameters have been involved in the development of noninvasive markers of hepatic fibrosis $[8,9]$ but the diagnostic performance of noninvasive biological scores in active IDUs remains to be determined.

In this study with young IDU patients with asymptomatic chronic hepatitis $\mathrm{C}$ we found that the effect of gender on AST and ALT elevations is lost in presence of HIV infection.

Elevations of AST and ALT are more frequent in men compared to women from general population [23]. In addition, gender has been associated with the prognosis of liver disease in patients with chronic hepatitis C [24, 25].

Our data also suggest that young IDUs with chronic hepatitis $\mathrm{C}$ and liver enzymes alterations could be evaluated for the presence of liver disease with more variables than those that are included in the majority of non-invasive biological scores for liver fibrosis. For instance, in the HCV monoinfected individuals, ALT elevations were associated with male gender, higher BMI, and younger age and in dual infected patients with higher CD4 cell count and lower total cholesterol.

Another strength from this study is the fact that patients were demographically distinct from series that include older and sicker patients with long-term chronic hepatitis $\mathrm{C}$; in this population of HIV+ IDUs without AIDS or end-stage liver disease, we found that age, total cholesterol, $\mathrm{CD}^{+}$, and alcohol consumption are predictors of liver enzyme alterations. However, GGT elevations are uniquely related to alcohol consumption in both the HCV monoinfected and the HCVHIV co-infected individuals.

In this study ALT elevation decreases with age in the monoinfected whereas the AST elevations increase with age in the co-infected group. Age, AST and ALT are regularly included in the FIB-4, one of the validated clinical indexes of liver fibrosis that has proved to correlate with liver fibrosis in mono and co-infected patients [26-28].

In the HCV monoinfected patients, BMI was one of the predictors for ALT elevations which has been previously found in other studies [29]. Although BMI is associated with hepatic steatosis [30] and progression of chronic hepatitis C it is not considered in the clinical indexes that estimate the extent of liver fibrosis.

We found that total cholesterol was related to AST and ALT elevations in co-infected patients, but not in the monoinfected. On average, higher levels of total cholesterol implied a lower prevalence of liver enzyme elevations suggesting that the HIV-related and/or chronic hepatitis C-related dyslipemia may play a role as reported previously in $\mathrm{HCV}$ monoinfected [17, 18] and HCV/HIV co-infected patients $[19,20]$.

With respect to cellular immunity, the absolute number of $\mathrm{CD}^{+}$cells was inversely associated with AST elevations in monoinfected patients, whereas increases of $\mathrm{CD}^{+}$cells and ALT were correlated significantly $(P<0.05)$ in the coin- fected group. Specific cellular immune responses in the course of chronic hepatitis $\mathrm{C}$ are crucial for inhibiting virus replication, even though it is not clear yet which subtype of lymphocytes contribute to control the progression of liver disease. Recent studies show the potential role of $\mathrm{CD}^{+}$ $\mathrm{CD} 25^{+}$cells (also called $\mathrm{CD} 25^{+}$Tregs), a small fraction of the peripheral $\mathrm{CD}^{+}{ }^{+}$cells, as regulatory $\mathrm{T}$ cells which can diminish hepatic damage by controlling the inflammation or stimulating the persistence of $\mathrm{HCV}$ infection [31-33]. In this study, cellular immunity was not measured as a specific response on $\mathrm{HCV}$ infection. However, absolute numbers of $\mathrm{CD}^{+}$and $\mathrm{CD}^{+}$cells were assessed in HIV-positive and HIV-seronegative IDUs thus making possible to analyze the role of cellular immunity in liver enzyme alterations.

Limitations in this cross-sectional study include the fact that IDU here analyzed may not be representative of the overall population; furthermore, IDU are heterogeneous regarding the patterns of substance abuse and severity of addiction. On the other hand, the potential selection bias may have influenced the results in the sense of that older patients with advanced liver disease were not represented in this study.

In conclusion, alterations of liver enzymes are frequent in young patients with chronic hepatitis $\mathrm{C}$ and they are influenced by HIV infection. Further studies are warranted to identify noninvasive markers for the clinical management of hepatitis $\mathrm{C}$ in this population particularly when liver biopsies are contraindicated

\section{ACKNOWLEDGEMENTS}

This work was partially supported by grants from Fundació La Marató de TV3 (02/1330) and Ministry of Health through the Carlos III National Institute of Health: Fondo de Investigación Sanitaria (FIS 05/1550) and Redes Temáticas y Centros de Investigación Cooperativa (RTIC RD06/001/ 0021 and RD06/006/1014).

\section{ABBREVIATIONS}

$\begin{array}{lll}\mathrm{HCV} & = & \text { Hepatitis } \mathrm{C} \text { virus } \\ \mathrm{IDU} & = & \text { Injection drug user } \\ \mathrm{AST} & = & \text { Aspartate aminotransferase } \\ \mathrm{ALT} & = & \text { Alanine aminotransferase } \\ \mathrm{GGT} & = & \text { Gamma glutamyltransferase } \\ \mathrm{BMI} & = & \text { Body mass index } \\ \mathrm{ART} & = & \text { Antiretroviral treatment } \\ \mathrm{OR} & = & \text { Odds ratio } \\ \mathrm{CI} & = & \text { Confidence interval } \\ \mathrm{IQR} & = & \text { Interquartile range } \\ \text { REFERENCES } & \end{array}$

[1] Inglesby TV, Rai R, Astemborski J, et al. A prospective, community-based evaluation of liver enzymes in individuals with hepatitis C after drug use. Hepatology 1999; 29(2): 590-6.

[2] Soriano V, Garcia-Samaniego J, Bravo R, et al. Interferon alpha for the treatment of chronic hepatitis $\mathrm{C}$ in patients infected with human 
immunodeficiency virus. Hepatitis-HIV Spanish Study Group. Clin Infect Dis 1996; 23: 585-91.

[3] Shakil AO, Conry-Cantilena C, Alter HJ, et al. Volunteer blood donors with antibody to hepatitis $\mathrm{C}$ virus: clinical, biochemical, virologic, and histologic features. The hepatitis C Study Group. Ann Intern Med 1995; 123: 330-7.

[4] Piton A, Poynard T, Imbert-Bismut F, et al. Factors associated with serum alanine transaminase activity in healthy subjects: consequences for the definition of normal values, for selection of blood donors, and for patients with chronic hepatitis C. MULTIVIRC Group. Hepatology 1998; 27(5): 1213-9.

[5] Centers for Disease Control and Prevention. Viral hepatitis C. Available from: http://www.cdc.gov/ncidod/diseases/hepatitis/c

[6] Garfein R, Doherty M, Monterroso E, et al. Prevalence and incidence of hepatitis $\mathrm{C}$ virus infection among young adult injection drug users. J Acquir Immune Syndr 1998; 18: S11-S19.

[7] Lackner C, Struber G, Liegl B, et al. Comparison and validation of simple noninvasive tests for prediction of fibrosis in chronic hepatitis. Hepatology 2005; 41: 1376-82.

[8] Wai CT, Greenson JK, Fontana R, et al. A simple non-invasive index can predict both significant fibrosis and cirrhosis in patients with chronic hepatitis C. Hepatology 2003; 38: 518-26.

[9] Forns X, Ampurdanés S, Llovet JM, et al. Identification of chronic hepatitis $\mathrm{C}$ patients without hepatic fibrosis by a simple predictive model. Hepatology 2004; 39: 862-3.

[10] Giannini E, Testa R. Noninvasive diagnosis of fibrosis: The truth is rarely pure and never simple. Hepatology 2003; 38: 1312-3.

[11] Sheth SG, Flamm SL, Gordon FD, Chopra S. AST/ALT ratio predicts cirrhosis in patients with chronic hepatitis $\mathrm{C}$ virus infection. Am J Gastroenterol 1998; 93: 44-8.

[12] Imbert-Bismut F, Ratziu V, Pieroni L, et al. Biochemical markers of liver fibrosis in patients with hepatitis $\mathrm{C}$ virus infection: a prospective study. Lancet 2001; 357; 1069-75.

[13] Leroy V, Vigan I, Mosnier JF, et al. Phenotypic and functional characterization of intrahepatic $\mathrm{T}$ lymphocytes during chronic hepatitis C. Hepatology 2003; 38: 829-41.

[14] Lechner F, Gruener NH, Urbani S, et al. CD8+ T lymphocyte responses are induced during acute hepatitis $\mathrm{C}$ virus infection but are not sustained. Eur J Immunol 2000; 30: 2479-87.

[15] Kim AY, Lauer GM, Ouchi K, et al. The magnitude and breadth of hepatitis $\mathrm{C}$ virus-specific $\mathrm{CD} 8^{+} \mathrm{T}$ cells depend on absolute $\mathrm{CD} 4^{+} \mathrm{T}$ cell count in individuals coinfected with HIV-1. Blood 2005; 105: 1170-8.

[16] Prati D, Taioli E, Zanella A, et al. Updated definitions of healthy ranges for serum alanine aminotransferase levels. Ann Intern Med 2002; 137: $1-10$

[17] Moriya K, Shintani Y, Fujie H, et al. Serum lipid profile of patients with genotype $1 \mathrm{~b}$ hepatitis $\mathrm{C}$ viral infection in Japan. Hepatol Res 2003; 25 : 371-6.
[18] Hofer B, Bankl HC, Wrba F, et al. Hepatocellular fat accumulation and low serum colesterol in patients infected with HCV-3 a. Am J Gastroenterol 2002; 97: 2880-5.

[19] Polgreen PM, Fultz SL, Justice AC, et al. Association of hypocholesterolaemia with hepatitis $\mathrm{C}$ virus infection in HIV-infected people. HIV Med 2004; 5: 144-50.

[20] Patroni A, Torti C, Tomasoni L, et al. Effect of HAART and hepatitis C coinfection on hyperlipidemia in HIV-infected patients: a retrospective longitudinal study. HIV Clin Trials 2002; 3: 451-61.

[21] Muga R, Sanvisens A, Egea JM, Tor J, Rey-Joly C. Trends in human immunodeficiency virus infection among drug users in a detoxification unit. Clin Infect Dis 2003; 37(Suppl 5): S404-S409.

[22] Hosmer DW, Lemeshow S. Applied logistic regression. New York: Wiley 1989.

[23] Pendino GM, Mariano A, Surace P, et al. Prevalence and etiology of altered liver tests: a population-based survey in a Mediterranean town. Hepatology 2005; 41: 1151-9.

[24] Di Martino V, Rufat P, Boyer N, et al. The influence of human immunodeficiency virus coinfection on chronic hepatitis $\mathrm{C}$ in injection drug users: a long-term retrospective cohort study. Hepatology 2001; 34: 1193

[25] Fuster D, Planas R, Muga R, et al. Advanced liver fibrosis in $\mathrm{HIV} / \mathrm{HCV}$-coinfected patients on antiretroviraltherapy. AIDS Res Hum Retroviruses 2004; 20: 1293-7.

[26] Sterling RK, Lissen E, Clumeck N, et al. Development of a simple noninvasive index to predict significant fibrosis in patients with HIV/HCV coinfection. Hepatology 2006; 43: 1317-25.

[27] Cacoub P, Carrat F, Bédossa P, et al. Comparison of non-invasive liver fibrosis biomarkers in HIV/HCV co-infected patients: The fibrovic study - ANRS HC02. J Hepatol 2008; 48: 765-73.

[28] Vallet-Pichart A, Mallet V, Nalpas B, et al. FIB-4: an inexpensive and accurate marker of fibrosis in $\mathrm{HCV}$ infection. Comparison with liver biopsy and fibrotest. Hepatology 2007; 46: 32-6.

[29] Leclercq I, Horsmans Y, De Bruyere M, Geubel AP. Influence of body mass index, sex and age on serum alanine aminotransferase (ALT) level in healthy blood donors. Acta Gastroenterol Belg 1999; 62: 16-20.

[30] Monto A, Dove LM, Bostrom A, et al. Hepatic Steatosis in HIV/Hepatitis C coinfection: prevalence and significance compared with hepatitis C monoinfection. Hepatology 2005; 42: 310-6.

[31] Chang KM. Regulatory T cells and the liver: a new piece of the puzzle. Hepatology 2005; 41: 700-2.

[32] Cabrera R, Tu Z, Xu Y, et al. An immunomodulatory role for CD4(+)CD25(+) regulatory $\mathrm{T}$ lymphocytes in hepatitis $\mathrm{C}$ virus infection. Hepatology 2004; 40: 1062-71.

[33] Accapezzato D, Francavilla V, Paroli M, et al. Hepatic expansion of a virus-specific regulatory $\mathrm{CD} 8(+) \mathrm{T}$ cell population in chronic hepatitis C virus infection. J Clin Invest 2004; 113: 963-72. 